\title{
Human sodium iodide transporter gene-mediated imaging and therapy of mouse glioma, comparison between ${ }^{188} \operatorname{Re}$ and ${ }^{131} I$
}

\author{
RUI GUO, YUN XI, MIN ZHANG, YING MIAO, MIAO ZHANG and BIAO LI \\ Department of Nuclear Medicine, Ruijin Hospital, School of Medicine, \\ Shanghai Jiaotong University, Shanghai 200025, P.R. China
}

Received February 18, 2016; Accepted November 16, 2017

DOI: $10.3892 / \mathrm{ol} .2018 .7752$

\begin{abstract}
Novel treatment options are urgently required for patients with glioma who are not effectively treated through standard therapy. Human sodium iodide symporter (hNIS) is a molecular target of certain tumors types. Compared with ${ }^{131} \mathrm{I}$, ${ }^{188} \mathrm{Re}$ possesses a higher energy and shorter half-life; therefore, the effects of ${ }^{188} \mathrm{Re}$ and ${ }^{131} \mathrm{I}$ were compared in hNIS-mediated gene imaging and therapy in the present study. Recombinant human brain glioma cell line U87 was transfected with a recombinant lentiviral vector containing hNIS (U87-hNIS). U87-0 cell line transfected with blank lentivirus was prepared as a control. In vitro, the ${ }^{188} \mathrm{Re}$ and ${ }^{131} \mathrm{I}$ uptake of U87-hNIS cells were 21.3-times and 25.9-times that of the control groups, however the excretion rate of the two nuclides was very rapid, and the half-life was only $\sim 4 \mathrm{~min}$. Sodium perchlorate inhibited hNIS-mediated ${ }^{188} \mathrm{Re}$ and ${ }^{131}$ I uptake to levels observed in the control groups. ${ }^{188} \mathrm{Re}$ and ${ }^{131}$ I were able to kill U87-hNIS cells selectively, with a survival of only 21.6 and $36.2 \%$, respectively. U87-hNIS nude mice appeared to accumulate ${ }^{188} \mathrm{Re}$, with a ratio of radioactivity counts between tumor and non-tumor sites of $\sim 13.5$ compared with 10.3 of ${ }^{131} \mathrm{I} 1 \mathrm{~h}$ after radionuclide injection. In contrast with in vitro studies, U87-hNIS cells demonstrated a notable increase in ${ }^{188} \mathrm{Re}$ retention in vivo, even $24 \mathrm{~h}$ after ${ }^{188} \mathrm{Re}$ injection. U87-hNIS cells also exhibited increased ${ }^{131}$ I retention in vivo; however, as the time increased, ${ }^{131}$ I was rapidly released with the tumor no longer able to be imaged $24 \mathrm{~h}$ after ${ }^{131} \mathrm{I}$ injection. Following treatment, U87-hNIS tumors experienced a volume reduction of $24.1 \%$, whereas U87-0 cells demonstrated an increase of $28.8 \% .{ }^{188} \mathrm{Re}$ and ${ }^{131} \mathrm{I}$ were revealed to be effective at decreasing tumor volume compared with the control. However, ${ }^{188}$ Re was significantly more potent compared with ${ }^{131} \mathrm{I}(\mathrm{P}<0.01)$. The present study indicated that the U87-hNIS cell line is sufficient to induce specific ${ }^{188} \mathrm{Re}$ and ${ }^{131} \mathrm{I}$ uptake, which may kill cells
\end{abstract}

Correspondence to: Professor Biao Li, Department of Nuclear Medicine, Ruijin Hospital, School of Medicine, Shanghai Jiaotong University, 197 Ruijin 2nd Road, Shanghai 200025, P.R. China E-mail: lb10363@rjh.com.cn

Key words: sodium iodide symporter, U87, ${ }^{188} \mathrm{Re},{ }^{131} \mathrm{I}$, therapy in vitro and in vivo. ${ }^{188}$ Re exhibited an increased retention time in vivo compared with ${ }^{131} \mathrm{I}$, which facilitates the imaging and therapy of U87-hNIS tumors.

\section{Introduction}

Glioma is one of the most common malignant tumor types globally with high morbidity and mortality. To date, surgical resection and radiotherapy remain the primary methods used for the treatment of glioma $(1,2)$. Radiotherapy requires at least 55 Gy of external radiation to control the tumor, however, a radiation dose of $>60$ Gy often results in normal brain tissue necrosis (3-5). Therefore, novel therapeutic strategies are required.

Sodium iodide symporter (NIS) is a type of cell membrane glycoprotein that mediates the active uptake of iodine in the thyroid and other types of tissues (6). Gene therapy is an important alternative for the treatment of tumors; for example, radioiodine treatment of extra-thyroidal cancer via the ectopic transfer of the NIS gene into otherwise non-NIS-expressing cancer. A number of studies have successfully obtained ectopic expression of NIS in different tumors through gene transfer (7-10). The dual function of NIS as a diagnostic and therapeutic gene thereby allows easy monitoring of functional NIS expression using $\gamma$ camera imaging techniques prior to the application of a therapeutic radionuclide dose (11). Our previous studies (12-15) demonstrated that baculovirus-mediated human NIS (hNIS) expression may mediate multiple tumor uptake of ${ }^{131} \mathrm{I}$, providing a promising target for gene therapy. In previous studies, extra-thyroidal tissues have generally not been able to mediate iodide organification following NIS gene transfer, therefore rapid outflow of ${ }^{131}$ I resulted in a decreased radiation dose able to affect the activity of tumor cells, thus decreasing the curative effect (16). The use of alternative NIS-transported radioisotopes with a higher energy than ${ }^{131}$ I may improve the efficacy of NIS-mediated radionuclide targeted therapy $(17,18) .{ }^{188} \mathrm{Re}$ is a type of short physical half-life radionuclide ( 0.71 days), which has been applied to treat various diseases, including prostate carcinoma, hepatoma carcinoma, breast carcinoma, bladder carcinoma, refractory arthritis and coronary beta-brachytherapy (19-22). Compared with ${ }^{131} \mathrm{I}(0.192 \mathrm{MeV})$, due to its high energy, ${ }^{188} \mathrm{Re}(23)$ is an ideal therapeutic alternative $(0.778 \mathrm{MeV})$. Our previous study (24) suggested that lentiviruses mediate hNIS expression 
that results in ${ }^{188} \mathrm{Re}$ uptake in glioma and provides a promising gene therapy strategy. However, the physical half-life of ${ }^{188} \mathrm{Re}$ is shorter (0.71 days) compared with that of ${ }^{131} \mathrm{I}$ (8.02 days). Therefore, the purpose of the present study was to compare the therapeutic effects of ${ }^{188} \mathrm{Re}$ - and ${ }^{131} \mathrm{I}$-mediated gene therapy in vitro and in vivo.

\section{Materials and methods}

Plasmid construction, lentivirus preparation and U87 cell transfection with lentivirus. Human NIS gene was obtained in the form of a pcDNA3.1-hNIS plasmid (provided by Dr Sissy Jhiang from Ohio University, OH, USA). U87 glioma cell line [American Type Culture Collection (ATCC), Manassas, VA, USA] was maintained in Dulbecco's modified Eagle's medium (DMEM; Gibco; Thermo Fisher Scientific, Inc., Waltham, MA, USA) containing $10 \%$ fetal bovine serum (Gibco; Thermo Fisher Scientific, Inc.), $100 \mathrm{U} / \mathrm{ml}$ penicillin and $100 \mu \mathrm{g} / \mathrm{ml}$ streptomycin (Gibco; Thermo Fisher Scientific, Inc.; $5 \% \mathrm{CO}_{2}, 37^{\circ} \mathrm{C}$ ). The plasmid containing hNIS was packaged into lentivirus vector (Thermo Fisher Scientific, Inc.) and named as Lenti-CMV-hNIS. To generate cell line expressing hNIS controlled by cytomegalovirus-enhancer/promoter, Lenti-CMV-hNIS was added to U87 cells at a multiplicity of infection of 2.0, then were selected for further study after 3 weeks. The transfected cell line stably expressing hNIS was named U87-hNIS. U87-hNIS was validated by radionuclide uptake experiments. Cells were inoculated with DMEM containing $10 \%$ fetal bovine serum, $100 \mathrm{U} / \mathrm{ml}$ penicillin and $100 \mu \mathrm{g} / \mathrm{ml}$ streptomycin in 24 -well plates $24 \mathrm{~h}$ prior to the experiment to achieve a density of $10^{5}$ cells per well at the day of experiment.

In vitro radioisotope uptake experiments. ${ }^{188} \mathrm{Re}$ was eluted from a ${ }^{188} \mathrm{~W} /{ }^{188} \mathrm{Re}$ generator (Jiangsu ReTai Pharmaceutical Biotechnology Co., Ltd., Changzhou, China) using $0.9 \%$ saline. ${ }^{131}$ I was supplied by Shanghai Kexin Biotech Co., Ltd. (Shanghai, China). In vitro ${ }^{188} \mathrm{Re} /{ }^{131} \mathrm{I}$ uptake experiments of U87-hNIS cells expressing hNIS were performed as Weiss and Grollman (25) described previously, with minor modifications. All data were corrected for attenuation. U87-hNIS cells were washed with $0.5 \mathrm{ml}$ buffered Hanks' balanced salt solution (bHBSS; containing $10 \mu \mathrm{M}$ HBSS and buffered with 4-(2-hydroxyethyl)-1-piperazineethanesulfonic acid, $\mathrm{pH} 7.3$ ), incubated in $0.5 \mathrm{ml}$ bHBSS (containing $3.7 \mathrm{kBq}$ ${ }^{188} \mathrm{Re} /{ }^{131} \mathrm{I}$ ) liquid for $1,2,5,10,20,30,60$ and $120 \mathrm{~min}$ respectively, then washed two times with ice-cold bHBSS, incubated with $1 \mathrm{ml}$ of $100 \%$ dehydrated ethanol for $20 \mathrm{~min}$, followed by cell lysis (using trypsin and $0.25 \%$ EDTA; Gibco; Thermo Fisher Scientific, Inc.). Finally, the radioactivity (count per min) was detected using a well gamma-counter (Shanghai Institute of Nuclear Research Rihuan Instrument Co., Shanghai, China) and compared with background, in order to achieve a ratio. All the following experiments were conducted in triplicate.

Sodium perchlorate inhibition study. The specificity of ${ }^{188} \mathrm{Re} /{ }^{131} \mathrm{I}$ uptake was investigated in the present study. U87-hNIS cells (at a density of $10^{5}$ ) were incubated with sodium perchlorate (Sigma-Aldrich; Merck KGaA, Darmstadt,
Germany) and $3.7 \mathrm{kBq}{ }^{188} \mathrm{Re} /{ }^{131} \mathrm{I}$ in DMEM containing $10 \%$ fetal bovine serum, $100 \mathrm{U} / \mathrm{ml}$ penicillin and $100 \mu \mathrm{g} / \mathrm{ml}$ streptomycin $\left(5 \% \mathrm{CO}_{2}, 37^{\circ} \mathrm{C}\right)$ for $30 \mathrm{~min}$, in which the concentration of sodium perchlorate was $0,1,2,5,10,20,50$ and $100 \mu \mathrm{M}$, respectively. Thereafter, the cells were washed with bHBSS twice, lysed (using trypsin and $0.25 \%$ EDTA; Gibco; Thermo Fisher Scientific, Inc.) at room temperature for three min, and their radioactivity measured, according to the methods aforementioned.

Radioisotope efflux study in vitro. The ${ }^{188} \mathrm{Re} /{ }^{131} \mathrm{I}$ efflux kinetics of U87-hNIS cells were investigated as previously described (25). U87-hNIS cells (at a density of $10^{5}$ ) were incubated with ${ }^{188} \mathrm{Re} /{ }^{131} \mathrm{I}(3.7 \mathrm{kBq} /$ well $)$ at $37^{\circ} \mathrm{C}$ for $\sim 30 \mathrm{~min}$. The culture medium (DMEM containing $10 \%$ fetal bovine serum) was then replaced with nonradioactive bHBSS. Cells were incubated for 2, 4, 6, 8, 10, 12, 14, 16, 18 or $20 \mathrm{~min}$ and immediately lysed using trypsin and $0.25 \%$ EDTA (Gibco; Thermo Fisher Scientific, Inc.). Subsequently, cells were extracted with $1 \mathrm{ml}$ dehydrated alcohol and the radioactivity in the cells was measured as aforementioned.

In vitro assessment of radioisotope toxicity by clonogenic assay. Prior to the experiment, U87-hNIS cells were cultured in 24-well plates, in order to achieve a density of $10^{5}$ cells/well at the day of study. As presented in Table I, cells were divided into five groups. Group 1 comprised U87-hNIS cells washed with bHBSS with $740 \mathrm{kBq}{ }^{188} \mathrm{Re}$, then cultured $\left(5 \% \mathrm{CO}_{2}, 37^{\circ} \mathrm{C}\right)$ for $7 \mathrm{~h}$. Group 2 was processed much the same as group 1, with the exception that ${ }^{188} \mathrm{Re}$ was replaced with ${ }^{131} \mathrm{I}$. Groups 3 and 4 were non-transfected U87 cells with ${ }^{188} \operatorname{Re}$ and ${ }^{131} \mathrm{I}$, respectively. Group 5 comprised non-transfected U87 cells without the addition of any radionuclide. Groups 3, 4 and 5 all served as controls. The 5 groups of cells were then washed and lysed as described above, and seeded in 6-well plates at a density of 200 cells/well. The cells were cultured for 7 days $\left(5 \% \mathrm{CO}_{2}\right.$ at $\left.37^{\circ} \mathrm{C}\right)$. Following removal of the culture medium as aforementioned, cells were stained with crystal violet solution $(0.1 \%)$ at room temperature for $10 \mathrm{~min}$ and the colonies $>30$ cells were counted using an optical microscope (x100 magnification; CKX41; Olympus Corporation, Tokyo, Japan). Results were expressed as the percentage of surviving cells compared with untreated U87 cells (Group 5).

Animal models. A total of 18 female 5-week-old athymic $\mathrm{Balb} / \mathrm{c}$ nude mice (18-20 g in weight) were used (Shanghai Laboratory Animal Centre Chinese Academy of Sciences, Shanghai, China). A full light-dark cycle with $10 \mathrm{~h}$ of light and $14 \mathrm{~h}$ of darkness each day was applied, with conditions including a temperature of $26-28^{\circ} \mathrm{C}$, a humidity of $40-60 \%$, and general feed and drinking water provided. Mice were sacrificed 4 weeks after the first intravenous injections of ${ }^{188} \mathrm{Re}$ or ${ }^{131} \mathrm{I}$. Animal experiments were approved by the Ethics Committee and Animal Care Committee of Shanghai JiaoTong University, School of Medicine (Shanghai, China). A xenograft model was generated by subcutaneous injection

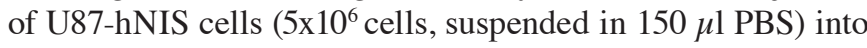
the right armpit of the mice. Subsequently, $\sim 6$ weeks following inoculation, the tumor diameters reached $0.8-1.0 \mathrm{~cm}$, which could be used for imaging and therapies. 
Table I. Subgroup of in vitro ${ }^{188} \mathrm{Re}$ and ${ }^{131}$ I clonogenic assay.

Characteristic Group 1 Group 2 Group 3 Group 4 Group 5

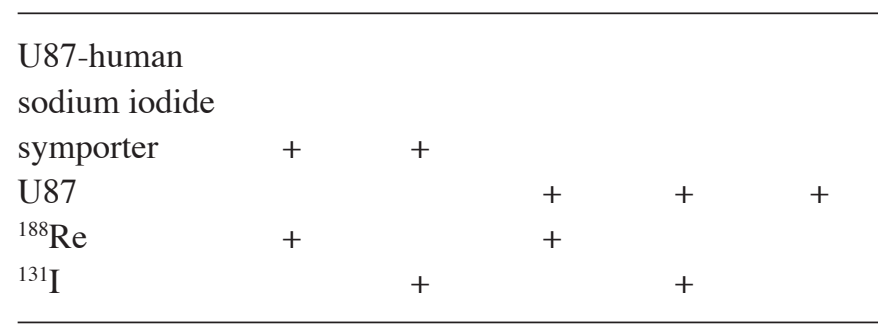

Tumor imaging and therapy study in a xenograft model. Tumor imaging studies were performed in six U87-hNIS nude mice. ${ }^{188} \operatorname{Re}(55.5 \mathrm{MBq})$ or ${ }^{131} \mathrm{I}(55.5 \mathrm{MBq})$ was injected through the caudal vein. Tumor images were performed $15 \mathrm{~min}$, $1,2,4$ and $24 \mathrm{~h}$ after injection using a high-resolution gamma camera equipped with a pinhole collimator (GE Healthcare Life Sciences, Little Chalfont, UK) immediately following ${ }^{188} \mathrm{Re}$ or ${ }^{131} \mathrm{I}$ injection. Each image lasted for $3 \mathrm{~min}$. The matrix size was $256 \times 256$. Region of interest was placed on the area of tumor and the contralateral axillary, and the ratio of radioactivity counts between tumor and non-tumor sites (T/NT) at each time point was measured.

Tumor therapy studies were performed in U87-hNIS nude mice at the same time. In the present study, no animal presented with multiple tumors, and when the tumor diameter of nude mice grew to $0.8-1.0 \mathrm{~cm}$ in diameter (the minimum and maximum diameter exhibited by a single tumor in the present study were 0.82 and $0.96 \mathrm{~cm}$, respectively), they were randomly divided into three groups $(\mathrm{n}=6)$. Group 1 was given two intravenous injections of $55.5 \mathrm{MBq}{ }^{188} \mathrm{Re}$ with an interval of 1 week. Group 2 was treated intravenously with 2 injections of $55.5 \mathrm{MBq}{ }^{131} \mathrm{I}$ with a 1 week interval. Group 3 was left untreated. In order to evaluate the therapeutic effect of hNIS mediated radionuclides, tumor size was measured with calipers prior to and following the administration of ${ }^{188} \operatorname{Re}$ or ${ }^{131} \mathrm{I}$ every week, in three dimensions. Tumor volume was estimated by the following formula: Length $\mathrm{x}$ width ${ }^{2} \mathrm{x} 0.52$.

Statistical methods. Origin 7.5 (OriginLab, Northampton, UK) and SPSS 16.0 (SPSS, Inc., Chicago, IL, USA) software were used in the present study. All experiments were performed in triplicates unless otherwise indicated. Numeric data are expressed as mean \pm standard deviation. One-way analysis of variance was performed to evaluate the difference amongst groups followed by Tukeys post hoc test. $\mathrm{P}<0.05$ was considered to indicate a statistically significant difference.

\section{Results}

Preparation of the lentiviruses. The lentiviral vector Lenti-cytomegalovirus (CMV)-hNIS containing CMV promoter and hNIS gene was packed successfully, and the Lenti-CMV-0 vector was packed as control. Stable cell lines U87-hNIS and U87-0 were established 3 weeks after infection with recombinant lentivirus. For the purpose of comparing hNIS mediated uptake of radioisotope in the cell

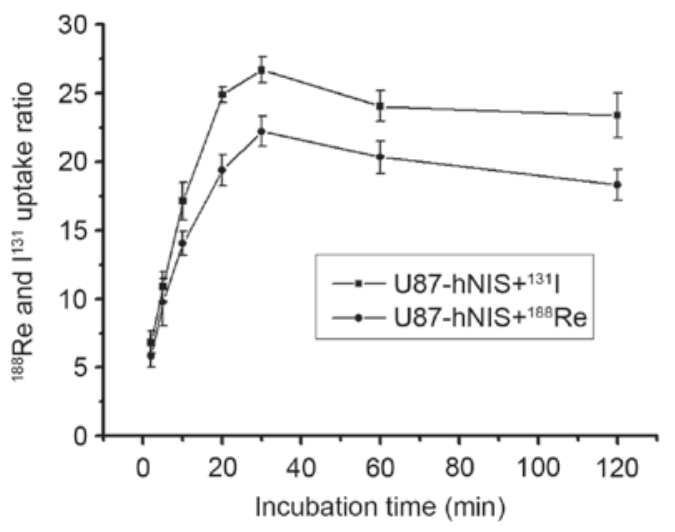

Figure 1. Effect of time on the ${ }^{188} \mathrm{Re}$ and ${ }^{131} \mathrm{I}$ uptake ratio (compared with background) in U87-hNIS cells. The ratio was measured following incubation for various periods of time with $3.7 \mathrm{kBq}$ of ${ }^{188} \mathrm{Re}$ and ${ }^{131} \mathrm{I}$ in buffered Hanks' balanced salt solution. Data are presented as the mean \pm standard deviation $(n=3)$. hNIS, human sodium iodide symporter.

line, ${ }^{188} \mathrm{Re}$ and ${ }^{131} \mathrm{I}$ uptake experiments were performed and compared in the following studies.

hNIS mediated in vitro radioisotope uptake. In U87-hNIS cells, uptake of ${ }^{188} \mathrm{Re} /{ }^{131} \mathrm{I}$ in relation to incubation time is presented in Fig. 1. The results reveal the initial ${ }^{188} \mathrm{Re} /{ }^{131} \mathrm{I}$ uptake dependent on incubation time. The results demonstrated that ${ }^{188} \mathrm{Re}^{/ 131} \mathrm{I}$ influx rapidly into U87-hNIS cells, reaching a peak at $30 \mathrm{~min}$. The ${ }^{188} \mathrm{Re}^{/ 131} \mathrm{I}$ uptake of U87-hNIS cells was measured to be 21.3 and 25.9-fold higher compared with that of U87-0 cells. The radioactivity measured $2 \mathrm{~h}$ after ${ }^{188} \mathrm{Re} /{ }^{131} \mathrm{I}$ incubation was 84.7 and $88.5 \%$ of the maximal uptake. ${ }^{131}$ I experienced an increased uptake compared with ${ }^{188} \mathrm{Re}$ in U87-hNIS cells. In a similar study performed by Zuckier et al (26), ${ }^{188} \mathrm{Re}$ and ${ }^{131} \mathrm{I}$ were reported to demonstrate a high uptake.

Sodium perchlorate inhibition study. In order to verify the specificity of hNIS mediated ${ }^{188} \mathrm{Re} /{ }^{131} \mathrm{I}$ uptake, ${ }^{188} \mathrm{Re} /{ }^{131} \mathrm{I}$ inhibition test was performed in U87-hNIS cells in the presence of varying concentrations of sodium perchlorate, an already confirmed competitive inhibitor. Fig. 2 presents the effect of distinct concentrations of sodium perchlorate on ${ }^{188} \mathrm{Re} /{ }^{131} \mathrm{I}$ uptake in U87-hNIS cells. When cells were treated with sodium perchlorate $(1-100 \mu \mathrm{M}),{ }^{188} \mathrm{Re}^{131} \mathrm{I}$ uptake in U87-hNIS cells was inhibited in a dose-dependent manner. At $5 \mu \mathrm{M}$, sodium perchlorate decreased ${ }^{188} \mathrm{Re} /{ }^{131} \mathrm{I}$ uptake to 15.3 and $18.1 \%$ of original levels, respectively, compared with and an inhibition rate of 96 and $95.3 \%$ at $50 \mu \mathrm{M}$. These results demonstrate that sodium perchlorate may specifically block ${ }^{188} \mathrm{Re} /{ }^{131} \mathrm{I}$ uptake in U87-hNIS cells, suggesting that ${ }^{188} \mathrm{Re} /{ }^{131} \mathrm{I}$ uptake in U87-hNIS cells is mediated by functional hNIS expression.

Radionuclide efflux assay. ${ }^{188} \mathrm{Re} /{ }^{131} \mathrm{I}$ efflux assays were performed $30 \mathrm{~min}$ after the addition of ${ }^{188} \mathrm{Re} /{ }^{131} \mathrm{I}$ into the cultured cells (the aforementioned cell uptake experiment identified that the highest intracellular uptake was obtained at $30 \mathrm{~min}$ ). The culture medium containing ${ }^{188} \mathrm{Re} /{ }^{131} \mathrm{I}$ was replaced by nonradioactive DMEM, the remaining ${ }^{188} \mathrm{Re} /{ }^{131} \mathrm{I}$ activity in U87-hNIS cell lysate was determined. As presented in Fig. 3, the intracellular radionuclides were released rapidly 


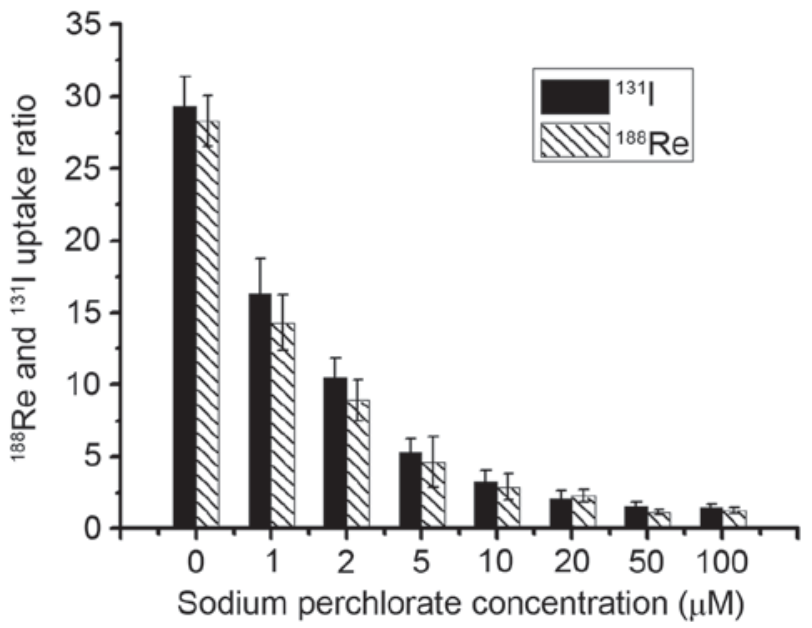

Figure 2. Sodium perchlorate inhibition study. Sodium perchlorate was added at the indicated concentrations $(0,1,2,5,10,20,50$ and $100 \mu \mathrm{M})$, ${ }^{188} \mathrm{Re}$ and ${ }^{131} \mathrm{I}$ uptake was measured as a ratio compared with background. Data are presented as the mean \pm standard deviation $(n=3)$.

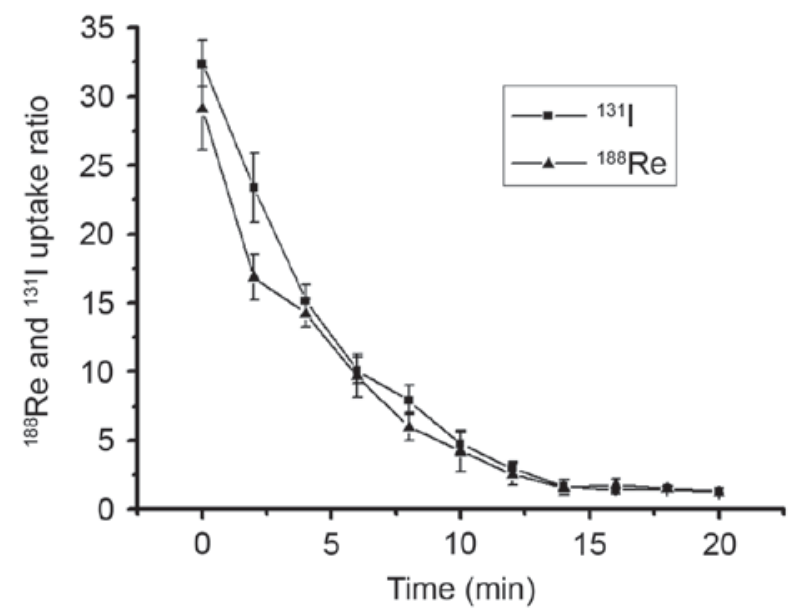

Figure 3. Time dependent ${ }^{188} \mathrm{Re}$ and ${ }^{131} \mathrm{I}$ efflux assay in U87-human sodium iodide symporter cells after 20 min incubation with $3.7 \mathrm{kBq}{ }^{188} \mathrm{Re}$ and ${ }^{131} \mathrm{I}$ in $0.5 \mathrm{ml}$ buffered Hanks' balanced salt solution. ${ }^{188} \mathrm{Re}$ and ${ }^{131} \mathrm{I}$ uptake was measured as a ratio compared with background. Data are presented as the mean \pm standard deviation $(\mathrm{n}=3)$.

into the medium, with $>50 \%$ of radionuclides excreted out of the cells within the first $4 \mathrm{~min}$, whereas a limited amount of residual radionuclide was observed $20 \mathrm{~min}$ after ${ }^{188} \mathrm{Re} /{ }^{131} \mathrm{I}$ was replaced by nonradioactive DMEM. These results suggested that radioactivity is rarely retained in U87-hNIS cells without reuptaking.

Radio toxicity assessed by colony-forming assay. Following treatment with ${ }^{188} \mathrm{Re} /{ }^{131} \mathrm{I}$, a colony-forming experiment was performed to calculate the survival rate of the cells. The results are presented in Fig. 4. The data are expressed as the percentage of surviving cells. In Groups 3 and 4, U87-0 cells were treated with ${ }^{188} \mathrm{Re} /{ }^{131} \mathrm{I}$, with the number of colonies representing 76.3 and $85.7 \%$ of the blank control group (Group $5)$, indicating that the two radionuclides exhibit nonspecific killing effects on U87-0 cells. Following treatment with ${ }^{188} \mathrm{Re} /{ }^{131} \mathrm{I}$, survival of Groups 1 and 2 were markedly decreased

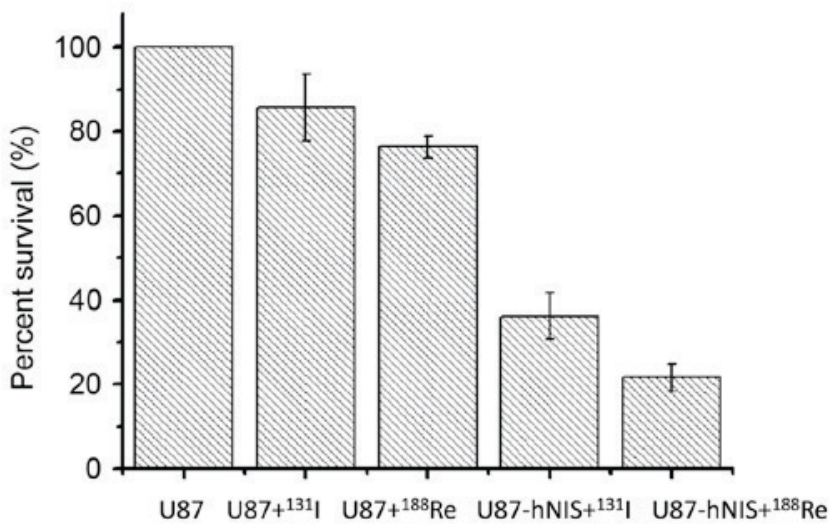

Figure 4. Survival rates of U87-hNIS cells treated with ${ }^{188} \mathrm{Re} /{ }^{131} \mathrm{I} .{ }^{188} \mathrm{Re} /{ }^{131} \mathrm{I}$ toxicity was assessed using a colony-forming assay. Cells were divided into 5 groups and treated as described on the $\mathrm{x}$-axis. Clones of $>30$ cells were counted. Results were expressed as the percentage of surviving clones obtained following treatment with ${ }^{188} \mathrm{Re} /{ }^{131} \mathrm{I}$. U87, U87 $+{ }^{131} \mathrm{I}$ and U87 $+{ }^{188} \mathrm{RE}$ served as controls. Data are presented as the mean \pm standard deviation $(n=3)$. hNIS, human sodium iodide symporter.

compared with that of the other 3 groups, with survival rates of only 21.6 and $36.2 \%$, respectively. These results suggest that ${ }^{188} \mathrm{Re} /{ }^{131} \mathrm{I}$ exhibits a selective killing effect on U87-hNIS cells, with an increased killing capacity of ${ }^{188} \mathrm{Re}$ compared with that of ${ }^{131} \mathrm{I}$.

Tumor imaging and therapy study. The results of in vivo uptake and efflux of ${ }^{188} \mathrm{Re} /{ }^{131} \mathrm{I}$ were different from those observed in vitro. U87-hNIS tumor demonstrated an efficient ${ }^{188} \mathrm{Re} /{ }^{131} \mathrm{I}$ uptake in vivo, which accumulated ${ }^{188} \mathrm{Re} /{ }^{131} \mathrm{I}$ rapidly and significantly as indicated by the arrows in imaging results of the right armpit in Fig. 5. Organs naturally expressing hNIS (such as the thyroid and stomach) and organs participating in ${ }^{188} \mathrm{Re} /{ }^{131}$ I excretion (such as the kidneys and bladder) were able to be visualized. Quantified results are presented in Fig. 6. The accumulation of ${ }^{188} \mathrm{Re} /{ }^{131} \mathrm{I}$ reached a peak $1 \mathrm{~h}$ after administration (T/NT, $13.5 \pm 3.2$ and $10.3 \pm 2.1$, respectively). ${ }^{188} \mathrm{Re}$ remained at a steady level until $24 \mathrm{~h}(\mathrm{~T} / \mathrm{NT}, 11.6 \pm 2.1)$, whereas ${ }^{131} \mathrm{I}$ experienced limited retention at $24 \mathrm{~h}(\mathrm{~T} / \mathrm{NT}, 3.9 \pm 0.7)$. Thyroid naturally expressing NIS markedly accumulated ${ }^{131} \mathrm{I} 24 \mathrm{~h}$ after injection, whereas ${ }^{188} \mathrm{Re}$ demonstrated limited accumulation (Fig. 5). As a result of lacking organification, ${ }^{188} \mathrm{Re}$ cannot be retained in the thyroid for a prolonged period of time, therefore its half-life is relatively short in the thyroid and may protect the thyroid from hypothyroidism. In contrast, ${ }^{131}$ I can be organified by the thyroid, which alongside a long half-life may increase the risk of hypothyroidism.

A total of 3 weeks following treatment, a difference in tumor volume was demonstrated among mice treated with ${ }^{188} \operatorname{Re}\left(409.6 \pm 113.4 \mathrm{~mm}^{3}\right),{ }^{131} \mathrm{I}\left(468.4 \pm 148.9 \mathrm{~mm}^{3}\right)$ and non-treated animals $\left(582.1 \pm 178.8 \mathrm{~mm}^{3}\right)(\mathrm{P}<0.05)$. No difference was observed between the ${ }^{188} \mathrm{Re}$ and ${ }^{131} \mathrm{I}$ treatment group at 3 weeks. The association between treatment group and tumor volume was more significant at 4 weeks post treatment. The tumor volume was significantly different between mice treated with ${ }^{188} \operatorname{Re}\left(317.2 \pm 72.1 \mathrm{~mm}^{3}\right),{ }^{131} \mathrm{I}\left(560.8 \pm 97.4 \mathrm{~mm}^{3}\right)$ and non-treated $\left(861.1 \pm 153.8 \mathrm{~mm}^{3}\right)(\mathrm{P}<0.01$; Fig. 7). Following therapy, ${ }^{188}$ Re treated U87-hNIS tumors experienced a volume 

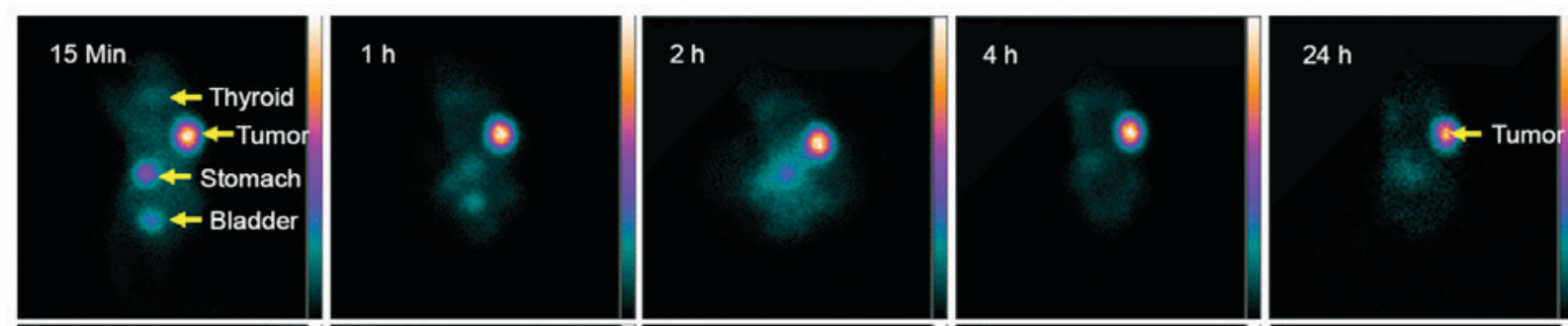

High
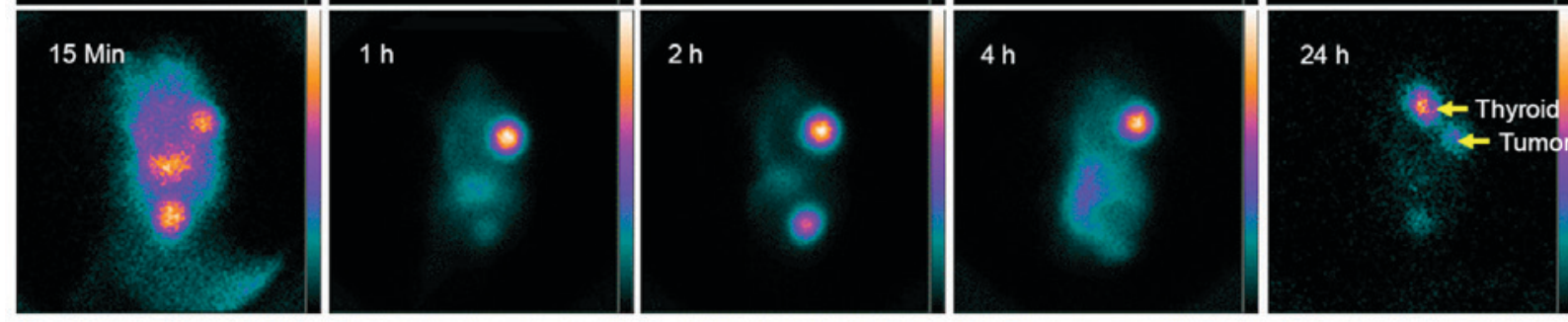

low

High

Figure 5. Scintigraphic images of nude mice treated with ${ }^{188} \mathrm{Re}$ (top row) and ${ }^{131} \mathrm{I}$ (bottom row). Mice were imaged with $55.5 \mathrm{MBq}{ }^{188} \mathrm{Re} /{ }^{131} \mathrm{I}$

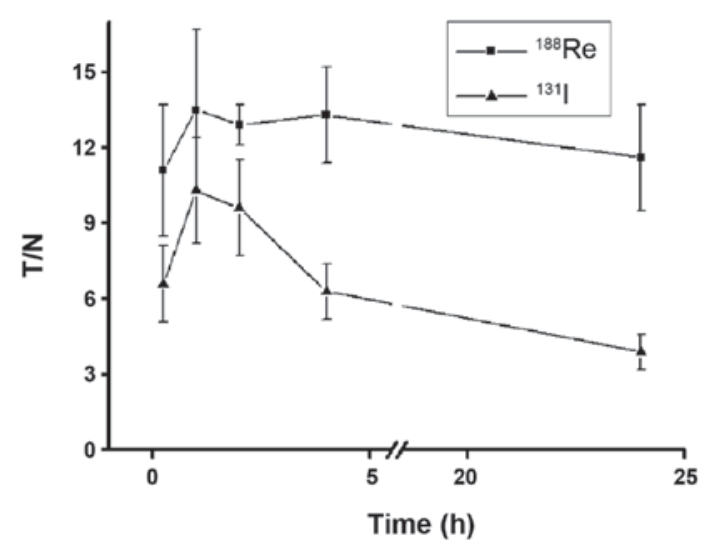

Figure 6. Time dependent T/NT of ${ }^{188} \mathrm{Re} /{ }^{131}$ I uptake by U87-human sodium iodide symporter tumor bearing nude mice. Data are presented as the mean \pm standard deviation $(n=6)$. T/NT, ratio of radioactivity counts between tumor and non-tumor sites.

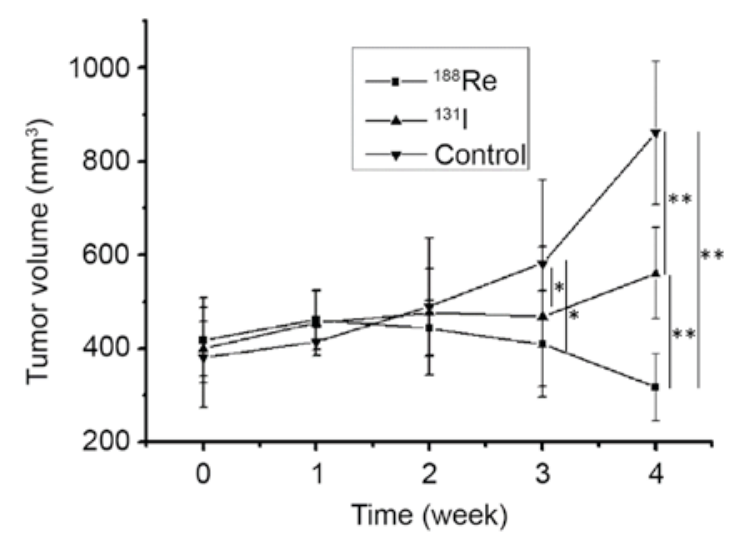

Figure 7. ${ }^{188} \mathrm{Re} /{ }^{131} \mathrm{I}$ decreased tumor growth in U87-hNIS tumor bearing nude mice, compared with control. $55.5 \mathrm{MBq}$ of ${ }^{188} \mathrm{Re} /{ }^{131} \mathrm{I}$ was injected intravenously into each mouse. The tumor size was measured prior to and following the administration of ${ }^{188} \mathrm{Re} /{ }^{131} \mathrm{I}$. Data are presented as the mean \pm standard deviation ( $\mathrm{n}=6$ ). hNIS, human sodium iodide symporter. ${ }^{*} \mathrm{P}<0.05$ and ${ }^{* *} \mathrm{P}<0.01$ with comparisons indicated by lines.

reduction of $24.1 \%$, whereas ${ }^{131}$ I treated U87-hNIS tumors demonstrated a volume increase of $28.8 \%$. ${ }^{188} \mathrm{Re}$ and ${ }^{131} \mathrm{I}$ were demonstrated to be effective at decreasing the tumor volume compared with the untreated control, with ${ }^{188} \mathrm{Re}$ revealed to exhibit an increased effect compared with ${ }^{131} \mathrm{I}(\mathrm{P}<0.01)$.

\section{Discussion}

NIS-mediated radionuclide therapy possesses several advantages (27), making it an attractive approach for glioma imaging and therapies. It does not require complex radiolabeling procedures, it also is small-sized allowing it to penetrate the blood brain barrier and diffuse into the tumor (28). Radioisotopes exhibit the potential of a bystander effect, which may destroy tumor cells without hNIS expression by radionuclides emitted from surrounding hNIS expression tumor cells (29). The hNIS gene is not expressed in normal cells however is in glioma cells (30), this indicates that it may assist in improving the specificity of tumor therapy and decreasing the damage to normal brain tissue.

${ }^{131} \mathrm{I}$ is an isotope commonly used in NIS-associated radionuclide therapy studies (31). However, as the radiation energy is not high enough, therapeutic efficacy of ${ }^{131} \mathrm{I}$ is limited (3). The use of a high-energy radionuclide also transported by NIS including ${ }^{188} \mathrm{Re}$, may be an effective strategy to improve therapeutic effect. A previous study demonstrated that ${ }^{188} \mathrm{Re}$ and ${ }^{125} \mathrm{I}$ share similar biodistribution patterns in mice, with the exception of the thyroid gland, as the thyroid gland has an organic function of iodine, which can retain ${ }^{125} \mathrm{I}$ (26). With lower $\gamma$-photons energy, ${ }^{188} \operatorname{Re}(155 \mathrm{keV})(32)$ is suitable for imaging, unlike ${ }^{131} \mathrm{I}(364 \mathrm{keV}) .{ }^{188} \mathrm{Re}$ can be easily generated using a ${ }^{188} \mathrm{~W} /{ }^{188} \mathrm{Re}$ generator (33). These attractive physical properties make ${ }^{188} \mathrm{Re}$ a promising candidate for tumor imaging and therapy (19). ${ }^{188}$ Re possesses a higher $\beta$ energy, but relatively shorter physical half-life compared with ${ }^{131} \mathrm{I}$ (34). Therefore, in the current study, the effects of ${ }^{188} \mathrm{Re}$ and ${ }^{131} \mathrm{I}$ in the treatment of glioma were compared in vivo and in vitro.

In the present study, it was demonstrated that a lentivirus containing CMV-hNIS expression cassette is able to transfect U87 cells, as revealed by efficient ${ }^{188} \mathrm{Re} /{ }^{131} \mathrm{I}$ uptake in U87-hNIS cells. ${ }^{188} \mathrm{Re} /{ }^{131} \mathrm{I}$ exhibit rapid uptake in U87-hNIS cells, and the dynamic uptake pattern of ${ }^{188} \mathrm{Re} /{ }^{131} \mathrm{I}$ was similar to that of previous studies $(30,31) .{ }^{188} \mathrm{Re}$ uptake 
of U87-hNIS was up to 21.3-times that of the U87-0 control group, whereas ${ }^{131}$ I uptake was up to 25.9 -fold of that of the control group. The two isotopes experienced a plateau phase akin to previous studies $(35,36)$, when the uptake and efflux of the isotopes reached a state of equilibrium (25). As with previous NIS studies, radionuclide retention time was short, and rapid outflow remained a problem in the in vitro studies, in the present study. Neither ${ }^{188} \operatorname{Re}$ nor ${ }^{131} \mathrm{I}$ experienced a long retention time in vitro.

In the in vitro experiments, isotope flow was rapid, with the outflow kinetics of the two radionuclides being similar. In addition, the colony formation assay demonstrated that U87-hNIS cells could be killed effectively by ${ }^{188} \mathrm{Re}$ and ${ }^{131} \mathrm{I}$. The absorbed dose of ${ }^{188} \mathrm{Re}$ was sufficiently high to selectively kill $78.4 \%$ of the cells, whereas ${ }^{131} \mathrm{I}$ was able to kill up to $63.8 \%$ of the cells. These data are sufficient to suggest that even with a lower uptake than that of ${ }^{131} \mathrm{I},{ }^{188} \mathrm{Re}$ may also be able to deliver a greater radiation dose to tumor cells, which is similar to the results reported by Kang et al (37) who identified that ${ }^{188} \mathrm{Re}$ uptake increased 87 -times, whereas ${ }^{125}$ I uptake increased 150-times in NIS transfected hepatocellular carcinoma cells, compared with untransfected cells. Following treatment with ${ }^{188} \mathrm{Re}$ or ${ }^{131} \mathrm{I}$, the survival rate of cells was 28.9 and $46.3 \%$ respectively. Therefore, a superior therapeutic effect of ${ }^{188} \mathrm{Re}$ was demonstrated.

In the in vitro study, cells in the culture dishes were arranged in a single layer, which is not a three-dimensional structure. Conclusions from the cells cannot be applied to solid glioma with a three-dimensional structure, which requires further confirmation in xenografts. In vivo, U87-hNIS glioma cells are close to each other, which allows for rapid reuptake of radionuclides in the cells and serves as a mechanism for isotope trapping by glioma. The results of the in vivo imaging investigations in the present study suggested that ${ }^{188}$ Re remained in U87-hNIS glioma cells even $24 \mathrm{~h}$ after administration, whereas a limited amount of ${ }^{131} \mathrm{I}$ was retained in the cells $24 \mathrm{~h}$ after treatment. The results of the present study suggest that ${ }^{188} \mathrm{Re}$ cannot be retained in the thyroid gland, as it cannot be organified. A previous study has reported a similar biodistribution pattern for ${ }^{131} \mathrm{I}$ and ${ }^{188} \mathrm{Re}(38)$. In fact, the thyroid will decrease the competitive uptake of ${ }^{188} \mathrm{Re}$, thereby decreasing thyroid injury and increasing tumor reuptake of ${ }^{188} \mathrm{Re}$, which is an advantage of hNIS-mediated radionuclide therapy in non-thyroid tumors. In addition, the results of the present study demonstrated that the degree of ${ }^{188} \mathrm{Re} /{ }^{131} \mathrm{I}$ uptake and retention are sufficient to achieve tumor therapeutic effects. Following treatment for 4 weeks, there was a significant difference in tumor size between ${ }^{188} \mathrm{Re}$ treated U87-hNIS mice and ${ }^{131}$ I treated U87-hNIS mice.

The present study also possessed a number of limitations. A stable hNIS transfected cell line was used to express hNIS, which could not be used directly in clinical practice. As a result of the variation of hNIS transfection efficiency and the difference in specificity, actual clinical efficacy of ${ }^{188} \mathrm{Re}$ and ${ }^{131}$ I requires further evaluation. It is reported that U87 MG ATCC cell line has been contaminated/misidentified, however it is most probably also a glioblastoma cell line (39). hNIS mediates uptake of iodine in thyroid and numerous types of non-thyroid cells (6), as a result, a number of previous studies have also successfully obtained ectopic expression of hNIS in different tumors by gene transfer (7-10). The main purpose of the present study was to compare the therapeutic effects of ${ }^{188} \mathrm{Re}$ and ${ }^{131} \mathrm{I}$ mediated by hNIS, rather than a study into the underlying molecular mechanisms of their effects, therefore the U87 cell line could be replaced with a variety of cell lines that express hNIS, as such the aforementioned misidentification/contamination issue is unlikely to have affected the outcomes of the present study.

In conclusion, the results of the present study demonstrated that ${ }^{188} \mathrm{Re}$ appeared to be more efficient than ${ }^{131} \mathrm{I}$ in the treatment of gliomas. The strategy appears to be a novel method for tumor imaging and therapy. However, improvements to decrease efflux and achieve increased radiation doses in the target tissue are still required.

\section{Acknowledgements}

The present study was supported by the National Natural Science Foundation of China (grant nos. 81101071 and 81471687) and the Medical Engineering (Science) Cross Foundation of Shanghai JiaoTong University (grant no. YG2013MS27).

\section{References}

1. D'Amico RS, Englander ZK, Canoll P and Bruce JN: Extent of resection in glioma-a review of the cutting edge. World Neurosurg 103: 538-549, 2017.

2. Sulman EP, Ismaila N, Armstrong TS, Tsien C, Batchelor TT, Cloughesy T, Galanis E, Gilbert M, Gondi V, Lovely M, et al: Radiation therapy for glioblastoma: American society of clinical oncology clinical practice guideline endorsement of the American society for radiation oncology guideline. J Clin Oncol 35: 361-369, 2017.

3. Prados MD and Levin V: Biology and treatment of malignant glioma. Semin Oncol 27 (3 Suppl 6): S1-S10, 2000.

4. Brandes AA, Rigon A and Monfardini S: Radiotherapy of the brain in elderly patients. Contra. Eur J Cancer 36: 447-452, 2000.

5. Grau JJ and Verger E: Radiotherapy of the brain in elderly patients. Pro. Eur J Cancer 36: 443-447, 2000.

6. Tazebay U, Wapnir IL, Levy O, Dohan O, Zuckier LS, Zhao QH, Deng HF, Amenta PS, Fineberg S, Pestell RG and Carrasco N: The mammary gland iodide transporter is expressed duringlactation and in breast cancer. Nat Med 6: 871-878, 2000.

7. Spitzweg C, Zhang S, Bergert ER, Castro MR, McIver B, Heufelder AE, Tindall DJ, Young CY and Morris JC: Prostate-specific antigen (PSA) promoter-driven androgen-inducible expression of sodium iodide symporter in prostate cancer cell lines. Cancer Res 59: 2136-2141, 1999.

8. Mandell RB, Mandell LZ and Link CJ Jr: Radioisotope concentrator gene therapy using the sodium/iodide symporter gene. Cancer Res 59: 661-668, 1999.

9. Cho J, Xing S, Liu X, Buckwalter TL, Hwa L, Sferra TJ, Chiu IM and Jhiang SM: Expression and activity of human $\mathrm{Na}+$ /I-symporter in human glioma cells by adenovirus-mediated gene delivery. Gene Ther 7: 740-749, 2000.

10. Dingli D, Diaz RM, Bergert ER, O'Connor MK, Morris JC and Russell SJ: Genetically targeted radiotherapy for multiple myeloma. Blood 102: 489-496, 2003.

11. Schmohl KA, Gupta A, Grünwald GK, Trajkovic-Arsic M, Klutz K, Braren R, Schwaiger M, Nelson PJ, Ogris M, Wagner $\mathrm{E}$, et al: Imaging and targeted therapy of pancreatic ductal adenocarcinoma using the theranostic sodium iodide symporter (NIS) gene. Oncotarget 16: 33393-33404, 2017.

12. Zhang M, Guo R, Xu H, Zhang M and Li B: Retinoic acid and tributyrin induce in-vitro radioiodine uptake and inhibition of cell proliferation in a poorly differentiated follicular thyroid carcinoma. Nucl Med Commun 32: 605-610, 2011.

13. Guo R, Zhang R, Pan Y, Xu H, Zhang M, Liang S, Wang L, Zhang Y and Li B: Feasibility of a novel positive feedback effect of 131I-promoted Bac-Egrl-hNIS expression in malignant glioma through baculovirus: A comparative study with Bac-CMV-hNIS Nucl Med Commun 32: 402-409, 2011. 
14. Guo R, Tian L, Han B, Xu H, Zhang M and Li B: Feasibility of a novel positive feedback effect of 131I-promoted Bac-Egr1-hNIS expression in malignant glioma via baculovirus. Nucl Med Biol 38: 599-604, 2011

15. Guo R, Zhang Y, Liang S, Xu H, Zhang M and Li B: Sodium butyrate enhances the expression of baculovirus-mediated sodium/iodide symporter gene in A549 lung adenocarcinoma cells. Nucl Med Commun 31: 916-921, 2010.

16. Mallick UK and Charalambous H: Current issues in the management of differentiated thyroid cancer. Nucl Med Commun 25 873-881, 2004

17. Nakamoto Y, Saga T, Misaki T, Kobayashi H, Sato N, Ishimori T, Kosugi S, Sakahara $\mathrm{H}$ and Konishi J: Establishment and characterization of a breast cancer cell line expressing $\mathrm{Na}+/ \mathrm{I}-$-symporters for radioiodide concentrator gene therapy. J Nucl Med 41: 1898-1904, 2000.

18. Dadachova E, Bouzahzah B, Zuckier LS and Pestell RG: Rhenium-188 as an alternative to iodine-131 for treatment of breast tumors expressing the sodium/iodide symporter (NIS) Nucl Med Biol 29: 13-18, 2002.

19. Lambert B and de Klerk JM: Clinical applications of 188Re-labelled radiopharmaceuticals for radionuclide therapy. Nucl Med Commun 27: 223-229, 2006.

20. Dadachova E, Nguyen A, Lin EY, Gnatovskiy L, Lu P and Pollard JW: Treatment with rhenium-188-perrhenate and iodine-131 of NIS-expressing mammary cancer in a mouse model remarkably inhibited tumor growth. Nucl Med Biol 32: 695-700, 2005

21. Höher M, Wöhrle J, Wohlfrom M, Kamenz J, Nusser T, Grebe OC, Hanke H, Kochs M, Reske SN, Hombach V and Kotzerke J: Intracoronary beta-irradiation with a rhenium-188-filled balloon catheter: A randomized trial in patients with de novo and restenotic lesions. Circulation 107: 3022-3027, 2003.

22. Murray A, Simms MS, Scholfield DP, Vincent RM, Denton G, Bishop MC, Price MR and Perkins AC: Production and characterization of 188Re-C595 antibody for radioimmunotherapy of transitional cell bladder cancer. J Nucl Med 42: 726-732, 2001.

23. Dadachova E, Bouzahzah B, Zuckier LS and Pestell RG: Rhenium-188 as an alternative to Iodine-131 for treatment of breast tumors expressing the sodium iodide/symporter (NIS). Nucl Med Biol 29: 13-18, 2002.

24. Guo R, Zhang M, Xi Y, Ma Y, Liang S, Shi S, Miao Y and Li B: Theranostic studies of human sodium iodide symporter imaging and therapy using 188Re: A human glioma study in mice. PLoS One 9: e102011, 2014

25. Weiss SJ, Philp NJ and Grollman EF: Iodide transport in a continuous line of cultured cells from rat thyroid. Endocrinology 114 1090-1098, 1984.

26. Zuckier LS, Dohan O, Li Y, Chang CJ, Carrasco N and Dadachova E: Kinetics of perrhenate uptake and comparative biodistribution of perrhenate, pertechnetate, and iodide by $\mathrm{NaI}$ symporter-expressing tissues in vivo. J Nucl Med 45: 500-507, 2004.
27. Ahn BC: Requisites for successful theranostics with radionuclide-based reporter gene imaging. J Drug Target 22: 295-303, 2014.

28. Dadachova E and Carrasco N: The Na/I symporter (NIS): Imaging and therapeutic applications. Semin Nucl Med 34: 23-31, 2004.

29. Carlin S, Cunningham SH, Boyd M, McCluskey AG and Mairs RJ: Experimental targeted radioiodide therapy following transfection of the sodium iodide symporter gene: Effect on clonogenicity in both two-and three-dimensional models. Cancer Gene Ther 7: 1529-1536, 2000.

30. Opyrchal M, Allen C, Iankov I, Aderca I, Schroeder M, Sarkaria J and Galanis E: Effective radiovirotherapy for malignant gliomas by using oncolytic measles virus strains encoding the sodium iodide symporter (MV-NIS). Hum Gene Ther 23: 419-427, 2012.

31. Chung JK and Cheon GJ: Radioiodine therapy in differentiated thyroid cancer. The first targeted therapy in oncology. Endocrinol Metab (Seoul) 29: 233-239, 2014.

32. O'Donoghue JA, Bardiès M and Wheldon TE: Relationships between tumor size and curability for uniformly targeted therapy with beta-emitting radionuclides. J Nucl Med 36: 1902-1909, 1995.

33. Sundram FX, Jeong JM, Zanzonico P, Divgi C, Bernal P, Chau T, Onkhuudai P, Knapp FF Jr, Buscombe J and Padhy AK: Trans-arterial rhenium-188 lipiodol in the treatment of inoperable hepatocellular carcinoma: An IAEA sponsored multi-centre phase 1 study. World J Nucl Med 1: 5-11, 2002.

34. De Ruyck K, LambertB, Bacher K, Gemmel F, De Vos F, Vral A, de Ridder L, Dierckx RA and Thierens H: Biologic dosimetry of 188Re-HDD/lipiodol versus 131I-lipiodol therapy in patients with hepatocellular carcinoma. J Nucl Med 45: 612-618, 2004.

35. Chen L, Altman A, Mier W, Lu H, Zhu R and Haberkorn U: $99 \mathrm{mTc}$-pertechnetate uptake in hepatoma cells due to tissue-specific human sodium iodide symporter gene expression. Nucl Med Biol 33: 575-580, 2006.

36. Boland A, Ricard M, Opolon P, Bidart JM, Yeh P, Filetti S, Schlumberger $\mathrm{M}$ and Perricaudet $\mathrm{M}$ : Adenovirus-mediated transfer of the thyroid sodium/iodide symporter gene into tumors for a targeted radiotherapy. Cancer Res 60: 3484-3492, 2000

37. Kang JH, Chung JK, Lee YJ, Shin JH, Jeong JM, Lee DS and Lee MC: Establishment of a human hepatocellular carcinoma cell line highly expressing sodium iodide symporter for radionuclide gene therapy. J Nucl Med 45: 1571-1576, 2004.

38. Willhauck MJ, Sharif Samani BR, Gildehaus FJ, Wolf I, Senekowitsch-Schmidtke R, Stark HJ, Göke B, Morris JC and Spitzweg C: Application of 188rhenium as an alternative radionuclide for treatment of prostate cancer after tumor-specific sodium iodide symporter gene expression. J Clin Endocrinol Metab 92: 4451-4458, 2007.

39. Allen M, Bjerke M, Edlund H, Nelander S and Westermark B: Origin of the U87MG glioma cell line: Good news and bad news. Sci Transl Med 8: 354re3, 2016. 